\title{
4. The Great Recession and the youth labour market in European countries: the demographic versus the labour market effect
}

\section{Piotr Michón}

\section{INTRODUCTION}

The goal of this chapter is to provide a simple labour supply explanation for the changes that took place in the youth labour market after the financial crisis. An extensive literature has examined the effects of the education system, of the economic situation and of employment protection legislation on youth labour force participation and its variability across countries and regions. By contrast, only very few studies address demographic changes and their consequences for youth labour markets (Bloom et al., 1987; Bloom and McKenna, 2015; Roth and Moffat, 2014). Until now researchers have not studied the effects of absolute and relative changes in the size of the youth population in the context of the recent economic and financial crisis. Although they have attempted to document the changes in the youth labour market (Bell and Blanchflower, 2011; O'Higgins, 2012), they have not considered the demographic aspects. Indirectly, researchers have assumed that changes in population size occur slowly and gradually. Thus, the assumption is that one needs to account for demographic changes when analysing long-term trends, whereas one may disregard such changes in short-run analyses of the labour market.

This contribution argues that neglecting demographic shifts has important consequences, both practically (for policymakers) and methodologically (for cross-country comparative analysis, in particular). The chapter aims to assess the impact of demographic shifts on the position of young people in the labour markets of European countries following the financial crisis (2008-09). The intention is to contribute to a broadening of social and labour market policy questions by providing evidence of the extent to 
which the labour market situation of young people may be worsened or improved by demographic change.

A typical approach to labour market changes involves analysis of (un) employment rates. However, any change in the number of working young people is a result of a combined demographic and labour market effect. Counterintuitively, if jobs for young people become more scarce, it is still possible for the youth employment rate to increase if the youth population decreases at an even faster rate. Vice versa, a growing number of young people in employment might lead to a decreased employment rate if the population of young people grows relatively faster. If a study is limited to employment rates, failing to take demographic changes into account, one may come to the misleading conclusion that an increase/decrease in the employment rate is always a sign of (un)successful policy.

In this chapter I will analyse changes in the relative and absolute size of the youth population in European countries. I will argue that because of decreasing levels of substitutability of young and older workers, it is necessary to focus on the absolute number of employed young people rather than on employment rates. The labour market has undergone significant structural changes in recent decades: nowadays when older workers leave the labour market, they are either replaced by experienced workers or their workplaces disappear, ultimately meaning that these workplaces are not available to young people.

In this context, decreasing substitutability means that young people become increasingly less likely to occupy the jobs left by older workers. When they enter the labour market, they mostly repeat the experience of their counterparts of a few years older. Thus, a decrease in the number of employed young people not only affects those who are already in the labour market, but also those who will enter it in the near future. This situation seems to be particularly significant when it comes to evaluating the consequences of such dramatic changes as the Great Recession (Bell and Blanchflower, 2011).

According to Eurostat Labour Force Survey (EU-LFS) data, the number of employed young people in the European Union decreased by 10 per cent between the first quarter of 2007 and the first quarter of 2017, which translates into nearly 4.2 million jobs. Moreover, we need to look at the changes in the youth labour market in a wider perspective. A shift towards a more positive situation on the (youth) labour market may be the result of emigration by young people and/or lower birth rates or a lower number of young people entering the labour market.

The message of this chapter is that if one observes a short-term improvement on the basis of traditional labour market indicators, it is likely that this improvement will distort policymakers' interpretations and decisions. 
What seems to be a recovery of the youth labour market, based on rising youth employment rates in some European countries after the Great Recession, may prevent policymakers from seeing the magnitude of the problems that young people and the whole of society face. A decreasing share of young people in the working-age population results in labour force ageing, lower economic growth and ultimately a need to reform many aspects of welfare state systems.

In this chapter I will argue that when carrying out cross-country evaluations of the youth labour market, one needs to consider changes in the absolute and relative size of youth populations. In order to highlight the youth labour market effect related to demographic changes as well as the effect related to national economies and labour market policies in European countries, the chapter provides an analytical framework that makes it possible to distinguish between these different effects. The disaggregate analysis of the changes in youth employment might shed light on the functioning of labour market institutions.

\section{THE GREAT RECESSION, THE YOUTH LABOUR MARKET AND THE DEMOGRAPHIC PERSPECTIVE}

From the perspective of a wide range of labour market outcomes, the Great Recession represented the deepest downturn in the post-war era. Alongside a rapid rise in unemployment rates, the deterioration of the youth labour market was hugely significant in most European countries. Young people became a kind of 'buffer' that absorbed the effects of the recession through wide fluctuations in their employment. The overall youth unemployment rates recorded for 2013 were high, particularly so in the first quarter of the year in Southern European countries such as Spain (53.4 per cent), Greece (57.9 per cent) and Croatia (53.7 per cent), although they also reached high levels in Italy (43.2 per cent; 2014Q1), Cyprus (37.6 per cent; 2014Q1), Portugal (38.8 per cent; 2013Q1) and the Baltic States (Estonia 36.4 per cent, Lithuania 34 per cent and Latvia 38.6 per cent; 2010Q1).

Low or decreasing levels of youth employment are not a new phenomenon. In the developed countries they have been a policy issue for the last few decades (Bell and Blanchflower, 2011; OECD, 2016b; Scarpetta et al., 2010). Employment of young people appears to be amongst the variables that are most sensitive to business-cycle fluctuations. There is strong evidence that when a national economy is strong, both young and adult workers are better off, whereas during recessions young people are more 
likely to be affected than older workers (OECD, 2016a). Young people are more vulnerable because their jobs are comparatively less protected by employers' interests, employment protection legislation and unions (e.g., through seniority rules). Because most young people have only recently entered the labour market, employers tend to perceive them as 'outsiders' (Solow, 1985). In a time of skill-biased technological progress and intensifying global competition, young people with low education and without work experience have difficulty finding a decent job. Additionally, in periods of labour market instability, especially, young people can be 'crowded out' by others with more knowledge and better skills who are willing to accept relatively poor jobs in order to remain employed. The challenge of finding a job and keeping it gains in importance when the consequences of failure are taken into consideration; that is, the scarring effect that significantly affects their lifetime earnings and upward mobility (Dolado et al., 2000; Gangl, 2002; Knabe and Rätzel, 2011; Nilsen and Reiso, 2011).

Most of the literature has treated this problem as 'youth related', which implies that when today's young people grow up the problems will disappear (even if they are likely to affect 'new' cohorts of young people, that is, those who are still children today). In other words, being young relates inherently to being at risk in the labour market. Thus, on this view, to improve the labour market position of youth it is necessary to focus on specific youth characteristics that reduce young people's chances of finding jobs in comparison to adult candidates.

However, we can also analyse the same problem from a very different, demographic perspective. As the size of cohorts entering the labour market changes, we might expect this variation to reduce (when the cohort is smaller) or increase (when the cohort is larger) the supply pressure on a labour market. Previous studies, mostly relating to the 'baby boom' generation, have identified the impact of demographic changes on the (un) employment of young people. The larger the cohort size, the higher the unemployment rate, the lower the wages and the lower the employment of young people (Brunello, 2009; Brunello and Lauer, 2004; Freeman and Wise, 1982; Korenman and Neumark, 2000; Roth and Moffat, 2014). Since younger and older workers are imperfect substitutes for each other, there will be an imbalance between them (Wachter and Kim, 1982). Consequently, the smaller the share of young people in the working-age population, the lower the risk of being unemployed when young (Freeman and Wise, 1982; Gómez-Salvador and Leiner-Killinger, 2008). Thus, shrinking youth cohorts could potentially improve the current youth employment situation. However, O'Higgins suggests that a successful strategy for dealing with the problem of youth unemployment would be to 
concentrate on aggregate demand rather than on the size of youth cohorts (O’Higgins, 1997).

In sum, the evidence on the demographic effects of changing the relative size of youth to adult cohorts is anything but clear cut (Gangl, 2002; Hannan et al., 1999). Since researchers in this field are generally looking for the effect of the relative (to adults) size of youth cohorts, or because they analyse countries where the changes in youth cohort size appear to be minor, they usually indicate that changes in youth (un)employment risks stem from changing economic conditions rather than from changes in the demographic size of youth cohorts (Gangl, 2002).

There are important reasons for considering demographic shifts when analysing the youth labour market consequences of the Great Recession. While in some countries the size of the birth cohort entering the labour market during and immediately after the recession remained stable, in others it changed dramatically (because of smaller or larger birth cohorts and/or migration). Additionally, in some countries the recession itself acted as a push for migration to other countries. As a result, youth labour market supply pressures have differed significantly across European countries.

\section{DATA AND METHOD}

In this study I have used the EU-LFS data available for the first quarter of each year during the period 2007-17. The age group for young people was defined as 20-29-year-olds and the working-age population was defined as 20-64-year-olds. In order to evaluate the effect of the Great Recession in 2017, I analysed the developments on youth labour markets in 33 European countries, starting from 2007, which was the last year before the financial crisis. The evaluation of young people's situation in the labour market builds mainly on the analysis of the employment ratio: the working youth population as a share of the total youth population.

According to the literature, demographic changes and their consequences for youth employment should be analysed along two dimensions: in relative terms and in absolute terms. In studying the changes in relative terms, I compared the following values: the ratio of the number of working young people to all working people (youth employment ratio) and the ratio of the number of young people to the number of all people of working age (youth population ratio). In analysing the changes in absolute terms, I compared changes in the number of young people (youth population size) and changes in the number of employed young people (youth employed population size). 


\section{RELATIVE CHANGES: YOUNG PEOPLE AS A PART OF THE WORKING-AGE POPULATION}

The literature has usually examined the impact of changes in the population age structure, in other words, the share of young people in the working-age population (e.g., Dixon, 2003; Heylen et al., 1996; Sunter, 2001). One might expect an increase in the proportion of young people to be accompanied by an improvement in their labour market opportunities. Young workers' employment prospects would thus improve as their share in the total labour force increases. This expectation builds on two indirect assumptions.

First, it may seem reasonable to assume a static labour demand in the short run. Thus, if the share of young people in the working-age population increases, so would their chances of finding employment because they would be competing for work with a relatively lower number of prime-age and older individuals. Second, we can assume that adult workers could substitute for young workers, and vice versa. Thus, an adult who withdraws from the labour market in some sense contributes to creating a job vacancy that becomes available for young entrants. As a result, the larger the proportion that young people make up of the working-age population, the better chance they have of being in work. Conversely, the lower the proportion of young people in the working-age population, the fewer chances for young people to find jobs.

Table 4.1 provides details of the changes in youth employment and the youth population. The most significant decline in the youth population ratio was reported in Ireland (-9.6 percentage points), Spain (-6.2 pp), Slovakia (-5.8 pp), Romania (-5.6 pp) and Poland (-5.2 pp). The ratio of young people to the total working-age population increased in 11 countries, with the Scandinavian countries leading the ranking - Denmark (increase of $4.1 \mathrm{pp}$ ), Sweden (3.3 pp) and Norway (2.4 pp) - whereas in the European Union (28 countries) the ratio decreased (-1.7 pp).

There is a positive and strong correlation (Pearson $=0.88$ ) between changes in the percentage of young people in the working-age population and changes in the percentage of young people in the employed population. During the decade between 2007 and 2017, the proportion of young people in the total employed population increased only in 7 out of 33 countries (Sweden, Denmark, Iceland, Norway, Luxembourg, the United Kingdom and Switzerland). However, in order to evaluate the changes adequately we also need to consider the demographic factors. In the same period youth increased their share in the total working-age population in all countries (except Switzerland).

If the share of young people in the working population increased relatively less than their share in the working-age population, this would 
Table 4.1 Relative changes in the youth share (aged 20-29) of the working-age population and the employed population

\begin{tabular}{|c|c|c|c|c|}
\hline & $\begin{array}{c}\text { Youth } \\
\text { employment } \\
\text { as a } \\
\text { percentage } \\
\text { of total } \\
\text { employment } \\
\text { (2017Q1) }\end{array}$ & $\begin{array}{l}\text { Change of the } \\
\text { ratio of youth } \\
\text { employment to } \\
\text { total employment } \\
\text { 2007Q1-2017Q1 } \\
\text { (percentage } \\
\text { points) }\end{array}$ & $\begin{array}{l}\text { Change of the } \\
\text { ratio of the youth } \\
\text { population to the } \\
\text { total working- } \\
\text { age population } \\
\text { 2007Q1-2017Q1 } \\
\text { (percentage points) }\end{array}$ & $\begin{array}{c}\text { Difference } \\
\text { (II-III) } \\
\text { between } \\
\text { changes } \\
\text { in youth } \\
\text { employment } \\
\text { and the youth } \\
\text { population }\end{array}$ \\
\hline & I & II & III & IV \\
\hline $\begin{array}{l}\text { European } \\
\text { Union (28 } \\
\text { countries) }\end{array}$ & $17.3 \%$ & -2.62 & -1.73 & -0.9 \\
\hline Austria & $20.3 \%$ & -0.20 & 0.53 & -0.7 \\
\hline Belgium & $17.8 \%$ & -1.92 & 0.34 & -2.3 \\
\hline Bulgaria & $14.3 \%$ & -3.08 & -0.97 & -2.1 \\
\hline Croatia & $17.5 \%$ & -3.73 & -2.21 & -1.5 \\
\hline Cyprus & $20.9 \%$ & -2.90 & -0.36 & -2.5 \\
\hline $\begin{array}{l}\text { Czech } \\
\text { Republic }\end{array}$ & $15.8 \%$ & -4.29 & -3.71 & -0.6 \\
\hline Denmark & $20.1 \%$ & 1.60 & 4.12 & -2.5 \\
\hline Estonia & $19.9 \%$ & -0.55 & -2.52 & 2.0 \\
\hline Finland & $18.5 \%$ & -0.04 & 0.76 & -0.8 \\
\hline France & $17.6 \%$ & -1.63 & -0.94 & -0.7 \\
\hline Germany & $17.8 \%$ & -0.30 & 0.26 & -0.6 \\
\hline Greece & $12.6 \%$ & -6.86 & -4.84 & -2.0 \\
\hline Hungary & $17.1 \%$ & -3.32 & -2.93 & -0.4 \\
\hline Iceland & $22.5 \%$ & 1.49 & 0.56 & 0.9 \\
\hline Ireland & $17.0 \%$ & -12.36 & -9.64 & -2.7 \\
\hline Italy & $11.7 \%$ & -4.09 & -1.35 & -2.7 \\
\hline Latvia & $18.8 \%$ & -2.96 & -3.75 & 0.8 \\
\hline Lithuania & $18.3 \%$ & -1.54 & -2.70 & 1.2 \\
\hline Luxembourg & $18.7 \%$ & 1.04 & 0.57 & 0.5 \\
\hline Macedonia & $17.6 \%$ & -0.86 & -2.66 & 1.8 \\
\hline Malta & $25.4 \%$ & -4.13 & -0.07 & -4.1 \\
\hline Netherlands & $20.8 \%$ & -0.10 & 1.90 & -2.0 \\
\hline Norway & $20.4 \%$ & 1.40 & 2.40 & -1.0 \\
\hline Poland & $19.0 \%$ & -4.41 & -5.15 & 0.7 \\
\hline Portugal & $15.0 \%$ & -5.04 & -4.14 & -0.9 \\
\hline Romania & $16.6 \%$ & -4.43 & -5.56 & 1.1 \\
\hline Slovakia & $17.9 \%$ & -5.94 & -5.76 & -0.2 \\
\hline Slovenia & $15.9 \%$ & -4.75 & -4.64 & -0.1 \\
\hline Spain & $12.7 \%$ & -9.94 & -6.17 & -3.8 \\
\hline Sweden & $20.1 \%$ & 2.54 & 3.34 & -0.8 \\
\hline
\end{tabular}


Table 4.1 (continued)

\begin{tabular}{lcccc}
\hline & $\begin{array}{c}\text { Youth } \\
\text { employment } \\
\text { as a } \\
\text { percentage } \\
\text { of total } \\
\text { employment } \\
\text { (2017Q1) }\end{array}$ & $\begin{array}{c}\text { Change of the } \\
\text { ratio of youth } \\
\text { employment to } \\
\text { total employment } \\
\text { 2007Q1-2017Q1 } \\
\text { (percentage } \\
\text { points) }\end{array}$ & $\begin{array}{c}\text { Change of the } \\
\text { ratio of the youth } \\
\text { population to the } \\
\text { total working- } \\
\text { age population } \\
\text { 2007Q1-2017Q1 } \\
\text { (percentage points) }\end{array}$ & $\begin{array}{c}\text { Difference } \\
\text { (II-III) } \\
\text { between } \\
\text { changes } \\
\text { in youth } \\
\text { employment } \\
\text { and the youth } \\
\text { population }\end{array}$ \\
\cline { 2 - 5 } & I & II & III & IV \\
\hline Switzerland* & $20.0 \%$ & 0.25 & -0.16 & 0.4 \\
Turkey & $24.1 \%$ & -5.70 & -5.00 & -0.7 \\
United & $21.9 \%$ & 0.41 & 0.82 & -0.4 \\
Kingdom & & & & \\
\hline
\end{tabular}

Notes: $\quad$ Employment ratio $=$ number of employed/size of population. Employment rate $=$ number of employed/size of active population. The data for Switzerland are for the period $2010-17$

Source: Author's own calculations based on Eurostat data (http://ec.europa.eu/eurostat/ statistics).

indicate a deterioration of the youth labour market situation. That was the case in Sweden, Denmark, Norway and the United Kingdom. The developments in these labour markets did not keep pace with the demographic shifts and, consequently, the labour market position of young people worsened.

In Iceland, Luxembourg and Switzerland the share of young people in the total employed population rose more than did the share of young people in the working-age population. Because of these quantitative changes, the situation of young people improved in these countries. They increased their participation in the labour market partly because of demographic changes and partly because they absorbed some of the 'adults' jobs'.

Considering the issue from the perspective of the labour market situation of young people, we find that if young people's share in the working-age population decreased faster than their share in the working population, the effect appeared to be favourable in the short run: It should be easier for young people to get a job. Between 2007 and 2017, that was the case in Estonia, Macedonia, Lithuania, Romania, Latvia and Poland. However, we need to assess these changes in a broader context. First, the observed demographic shift meant that the working-age population became older 
in these countries. Second, adults took over some of the jobs previously occupied by young people. This might lead to difficulties in entering the labour market for future generations of youth. Third, while it could be an effect of emigration, we might ask why the proportion of young people in the working-age population dropped. The conclusion that the labour market situation improved because a significant number of young people left the country would be rather ambiguous.

The recession and post-recession period brought particularly negative consequences for young people in the southern European countries (Spain, Italy, Cyprus, Bulgaria, Greece, Croatia, Portugal and Turkey), in Belgium, Ireland, Austria, France and the Czech Republic, and to lesser extent in Hungary, Slovakia and Slovenia. Over the decade, a disproportionately large decline in young people's share of total employment accompanied the decline in their share of the working-age population in these countries. Unlike in the countries analysed in the previous paragraph, the situation of young people in the labour market did not improve, not even in the medium term.

Limited substitutability. The existing literature (e.g., Korenman and Neumark, 2000) has tended to focus on the impact of shifts in the share of young people in the working-age population. One might expect that if the proportion of young people increases, their labour market opportunities would improve. As mentioned before, this expectation builds on two indirect assumptions: a static demand for labour and full substitutability. The first assumption implies that if an adult withdraws from the labour market, his or her job will become available for the young (and vice versa). In other words, if young people increase their share of the working-age population, they are likely to improve their labour market situation - if there is a substitutability between the young and the old. However, scholars have questioned the reasoning behind the assumption (e.g., Korenman and Neumark, 2000), arguing that younger and older workers are not perfect substitutes for each other. Thus, changes in the relative size of youth cohorts have only a limited effect on the youth labour market. Most previous studies have confirmed that the size of the old cohorts leaving the labour market does not affect young people, neither in terms of employment or unemployment, nor with respect to occupational allocation (Gangl, 2002).

Moreover, the existing literature suggests that substitutability between younger and older workers declines as skills, education and experience gain in importance (Bell and Blanchflower, 2011). The growing importance of qualifications and high-skilled labour is evident in European economies. Consequently, there will be an increasing demand for highly skilled, well-educated and experienced workers, which are criteria that 
many young people are unable to meet. Lower-educated young people suffer more during economic recessions than do the higher skilled (Gangl, 2002). Analyses of the longer-term trends in youth labour markets even indicate more lasting changes that favour adult and more experienced workers over young people (Korenman and Neumark, 2000).

Although the changes in the active population age structure contribute to the changing situation of young people in labour markets in the advanced economies, recent empirical studies provide contradictory results. For example, Bell and Blanchflower (2011) observed that despite a decline in cohort size, the relative labour force performance of young people in the United States and the United Kingdom worsened in the 1980s and 1990s. I would argue that it is at least partly because of the limited substitutability between younger and older workers that the changes in the absolute cohort size gain on importance. A lower number of young people entering the labour market translates into fewer individuals competing, ceteris paribus, for the same number of vacancies. Hence, they have easier access to jobs and face a lower risk of unemployment. Vice versa, if a greater number of young people compete for the same number of vacancies, they face more difficulty in finding employment and a higher risk of joblessness.

\section{ABSOLUTE CHANGES: THE SIZES OF THE YOUTH POPULATION AND THE YOUTH-IN- EMPLOYMENT POPULATION}

From the perspective of 2017, many European countries seemed to experience bouts of recovery that were strong enough to drive up youth employment ratios significantly (see Figure 4.1). Indeed, the share of employed youth was relatively higher in the Eastern European countries than in the pre-crisis period. Other countries, such as Spain, Greece, Cyprus, Ireland and Denmark, did not recover their levels of youth employment. When comparing the trends in youth employment, it is easy to suggest that one country was doing badly compared to other countries. However, I find it essential to place such statements in a broader context.

\section{THE SIZE OF THE YOUTH POPULATION}

Many researchers (e.g., Breen, 2005; Lewis and Heyes, 2017) developed analytical models in which they, directly or indirectly, assumed that all age cohorts were of equal size. The assumption might be effective for a shortterm analysis, but it fails to provide a realistic picture of the alternation 


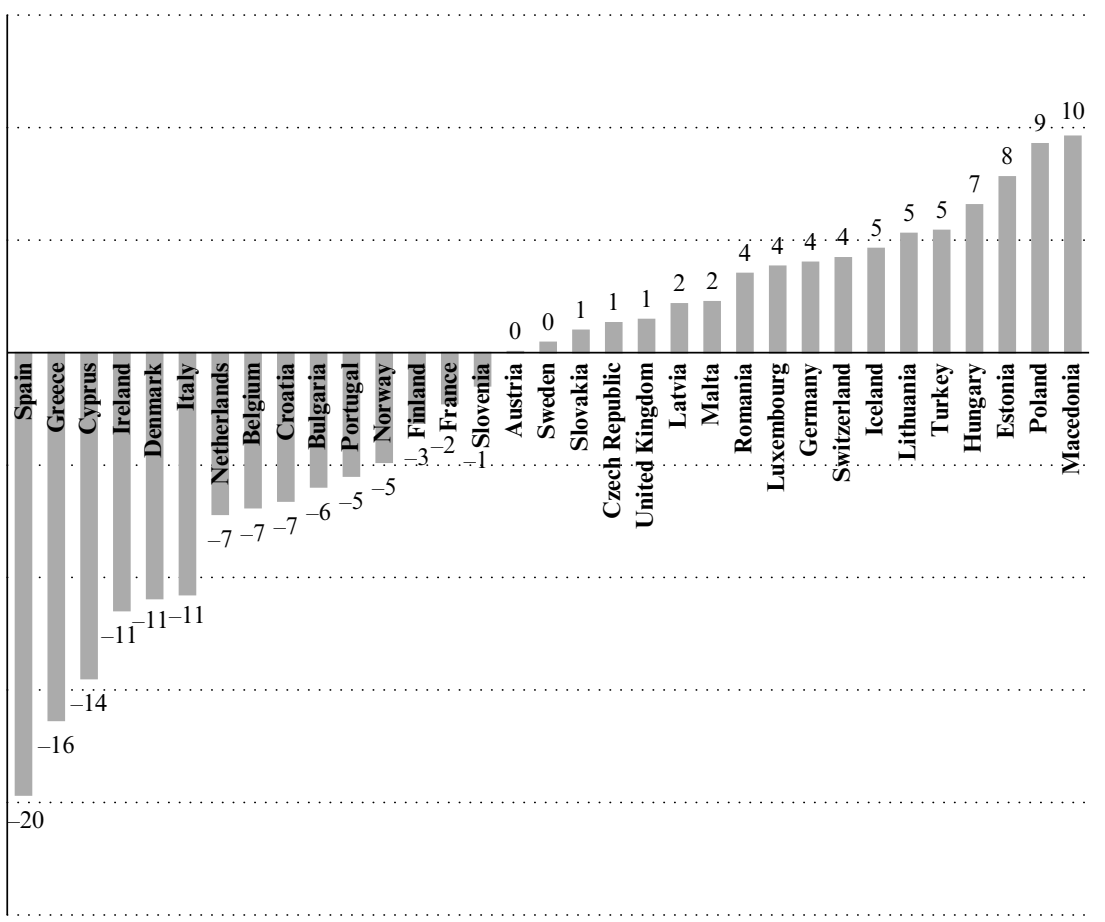

Source: Author's own calculations based on Eurostat data (http://ec.europa.eu/eurostat/ statistics).

Figure 4.1 Change in youth (aged 20-29) employment to youth population ratios in the period 2007Q1 to 2017Q1 (percentage points)

that results from sudden and major changes in the economic situation (as in the Great Recession) or if one adopts a long-term and cross-national perspective.

Numerous studies (Bloom and Canning, 2004; Connelly, 1986; Nahum and Dahlberg, 2003; Roth and Moffat, 2014; Wachter and Kim, 1982) have analysed the effect on labour market supply of an increasing number of young people. These publications indicate that when the number of young people increases, it adds to the supply pressure and consequently has a negative effect on the labour market situation of young people. In contrast to the research focused on changes in the share of young people in the working-age population, these studies examined changes in the absolute size of the youth population, that is, the changes in the number 
of young people over time. For example, the ILO analysis of the global employment trends for youth showed that the youth population grew quicker than youth labour force participation and employment (ILO, 2015). This led to intensified supply pressure on the labour market, and to lower activity and employment rates. The ILO analysis indicated that the demographic surge might explain the high youth unemployment rate in many countries. However, this seems not to have been the case in the European countries. Contrary to the global trends, the youth population in the European region decreased during the decade 2007-17. At the end of the decade the number of young people (aged 20-29) in 28 European Union countries was slightly less than 59.6 million, which amounts to a decrease of 5.03 million compared to ten years previously ( 8 per cent). The analysis also revealed the significant differences between the European countries (see Figure 4.2). Whereas in the Scandinavian countries (i.e., Norway, Sweden and Denmark) the population of young people increased by one fourth, in the same period it decreased substantially in Ireland, Romania, Spain and Latvia.

Demographic pressures affect youth labour market outcomes primarily via changes in the relationship between the supply of workers and the number of available vacancies (i.e., labour demand). If more young people compete for the same number of vacancies, this should lead to greater difficulties in finding jobs, ceteris paribus, and thus increase the risk of unemployment or inactivity (young people not in employment, education or training: NEETs). Vice versa, the lower the number of individuals competing for the same number of vacancies, the lower the pressure on the labour market, and thus the lower the risk of unemployment. In the short-term perspective, a decreasing number of people entering a national labour market may result in a fall in unemployment, and in a rise of both employment and activity rates. In the long-term perspective, the decreasing labour supply can make it difficult to recruit workers. Thus, in turn, such a shortage in supply can be an obstacle to sustained growth.

With employment growth expected to slow down and emerging labour market shortages, the Czech Republic is a good example of a country where one could expect demographic changes to constrain potential growth in the coming years. Labour supply issues will become a significant concern for many ageing societies. Countries like Poland and Hungary, which have the highest old-age dependency ratio and low shares of the older population currently participating in the labour market, will face the greatest challenges.

The changing population of people in the same age group affects the situation of these people in the labour market. If the number of people in an age group increases over a period, so too will the supply pressure on 


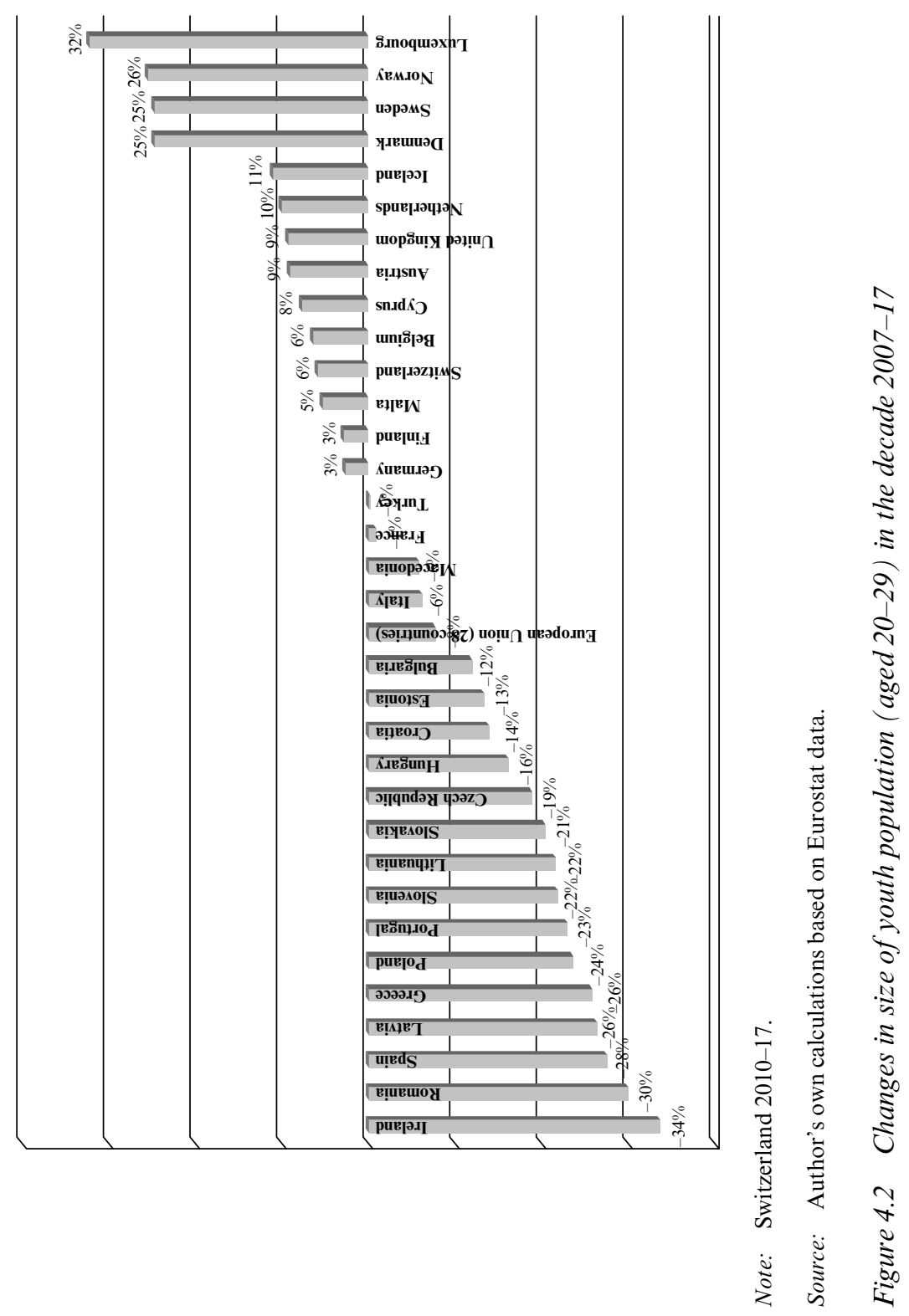


the labour market (generation crowding out). Conversely, if the number decreases, the pressure becomes weaker. Consequently, if the number of individuals in an age group remains stable over a period of time, the labour market pressure remains unchanged. Overall, the demographic effect reflects the balance of emigration and immigration and the changes in the birth cohort size between period $t$ and period $t+1$.

However, a decrease in the number of young people in the labour market does not automatically lead to an increase in the youth employment rate. There are two explanations for this. First, a skill mismatch: if young people do not have the skills that employers require, the young job applicants are less likely to get a job. Second, young people might not be the first-choice option of employers. As demand for experienced workers increases, so too may the traditional labour reservoir, for instance, mothers of young children and older people. Many European countries face a potential shortage of high-skilled workers, and this explains why labour market outcomes become more differentiated by education levels. The employment rates of highly skilled workers are at about EU average, while the employment rates of the low and medium skilled are below the average.

Bearing in mind that during the period under study demographic changes varied across European countries, it is worth assessing their impact on the youth labour market. For this purpose, I have analysed the changes in the size of the youth population, including the changes in the number of young people in employment. In order to show the relative effect of the demographic changes, I have compared four pairs of countries that recorded similar changes in the youth employment to youth population ratio between 2007 and 2017: (1) Denmark and Ireland, (2) Greece and Cyprus, (3) Poland and Iceland, and (4) Lithuania and Germany.

Denmark and Ireland experienced a similar drop in the youth employment ratio. In both countries the youth employment ratio (employed youth as a share of the total youth population) dropped by $11 \mathrm{pp}$ (see Figure 4.1) between 2007 and 2017. However, the two countries differ significantly in terms of their demographic shifts. While the population of young Danes increased by 25 per cent in the same period, the population of young Irish people dropped by 34 per cent. Although in Denmark and Ireland the changes in employment ratio between 2007 and 2017 were very similar (see Figure 4.1), the reasons behind the changes and the future consequences were significantly different. In Denmark the employment rates of young people dropped because the increase in the number of jobs held by young people (7 per cent) (see Figure 4.3) was relatively weaker than the increase in population size ( 25 per cent) (see Figure 4.2). In Ireland, by contrast, the number of employed young people decreased (Figure 4.3) by 34 per cent 


\section{Denmark}

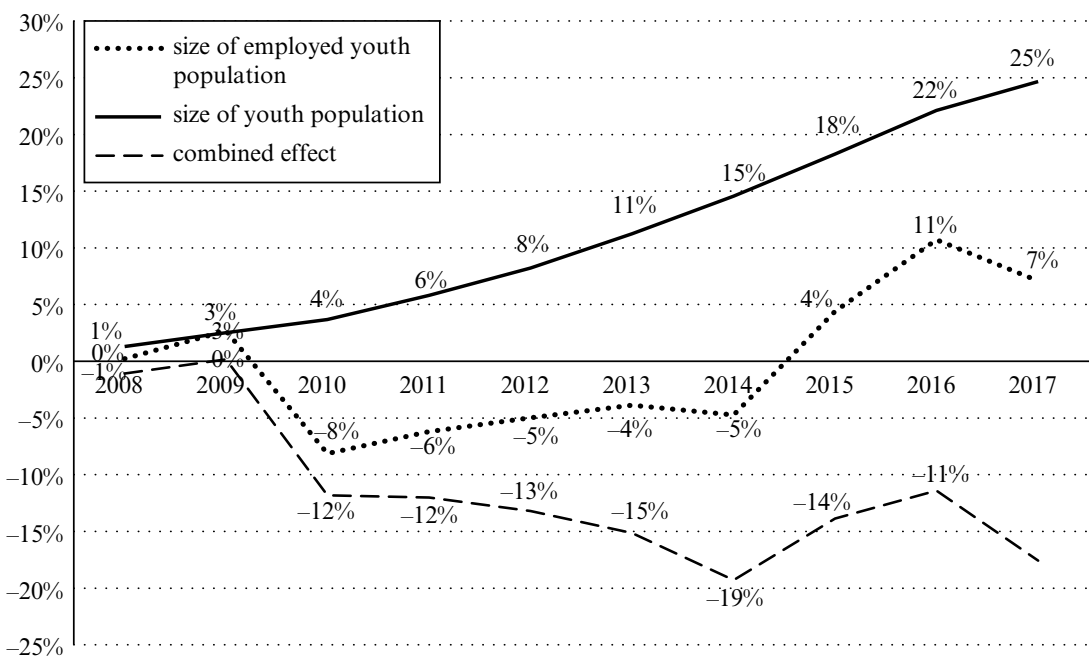

Ireland

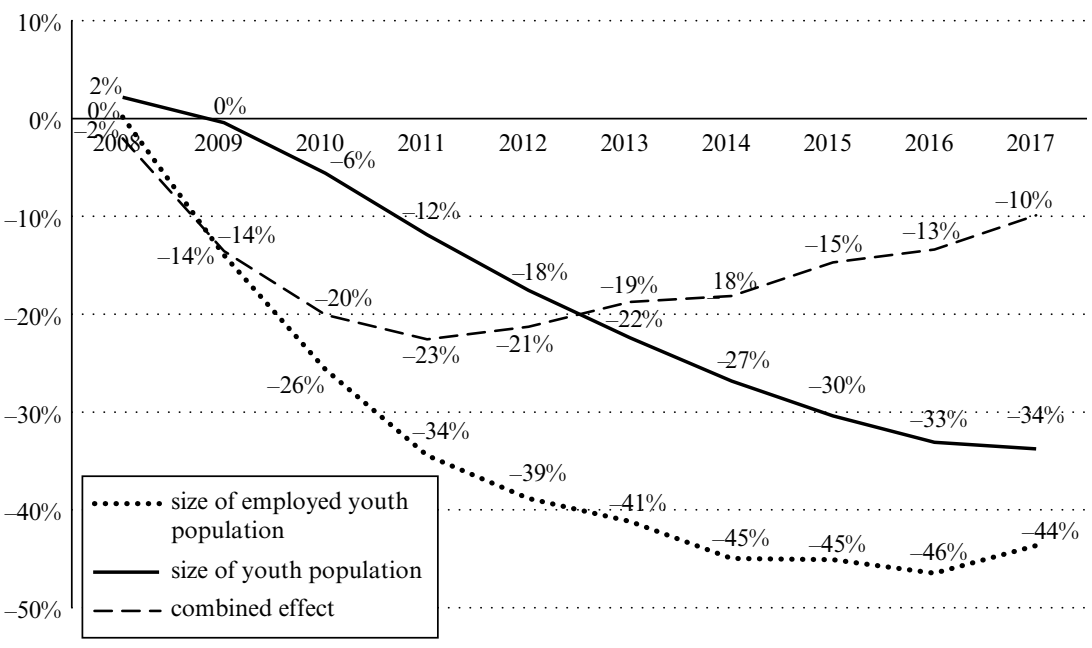

Source: Author's own calculations based on Eurostat data.

Figure 4.3 Changes in size of youth population (aged 20-29) and number of young people (aged 20-29) in employment 2007-17 
between 2007 and 2017, but in the same period the population of all young people in Ireland (20-29) decreased even more - by 44 per cent (see Figure 4.3). Due to the combined effect of a lower fertility rate and migration, the population of young Irish people decreased between 2007Q1 and 2017Q1 by 137.7 thousand in the age group $20-24$ and by 120.6 thousand in the age group 25-29.

When the aim is to improve the youth labour market in conditions of limited substitutability of young and older workers, an increasing the number of young people in employment is very desirable. However, the difference between the size of growth of the youth population and youth employment in Denmark may be due to a larger performance gap between first-generation immigrants and non-immigrants. Young people born to immigrants are much more likely to be unemployed and inactive compared to young people whose parents were born in Denmark (the same is true for adult workers). The gap is one of the highest in the EU, with migrant women being in a particularly unfavourable situation (European Commission, 2017). Obviously, the situation of migrants does not explain all the changes in the labour market, but it seems to provide an important part of the explanation.

In 2017, in Lithuania and Germany, the employment-to-population ratio of young people was relatively higher than in 2007, by 5 pp and 4 $\mathrm{pp}$, respectively. However, the analysis of the absolute number of people in employment reveals a significant difference between the two countries. While in Germany the number of employed young people increased by 9 per cent, in Lithuania it dropped by 14 per cent. We see a similar effect in the changes in employment rates, which were mostly due to substantial differences in demographic shifts. During the decade the population of young Lithuanians fell by more than 21 per cent, while the number of young Germans increased by 2 per cent.

Lithuania, as well as the other Baltic States, experienced a dramatic change in the size of the working-age population. Because of massive redundancies and severe cuts in social security benefits, large groups of people decided to emigrate. Labour emigration from Lithuania and Latvia almost doubled during and after the crisis, with the trend also observed in Estonia, albeit at a lower level (Gonser, 2011). In 2012, Latvia, Estonia (where one in four young people have emigrated) and - remarkably Lithuania (where the share reached 45 per cent) were amongst the EU countries with the largest proportions of young people leaving their country of residence to settle in another EU member state (European Commission, 2015). The Baltic States were clearly countries from which many young people were moving abroad (European Commission, 2016). Most people emigrating from Estonia have been young and the emigrating 
population increased systematically between 2005 and 2013 (Statistics Estonia, 2015). The studies from the Baltic States have shown that unemployment was the main reason for emigration during and after the crisis (Apsìte et al., 2012; Rakauskienè and Ranceva, 2014; Veidemann, 2010).

In the short-term perspective, emigration of young people reduces the pressure on the labour market, but in the long term it leads to very negative consequences: for instance, it accelerates the ageing of a society, decreases the role of young people in the democratic system and puts the future of pension systems at risk.

Between 2007 and 2017, Greece and Cyprus faced a similar change of youth employment to youth population ratio: $16.4 \mathrm{pp}$ and $14.5 \mathrm{pp}$, respectively. However, a closer analysis revealed substantial differences. While the Greek youth population declined substantially (by 26 per cent), the youth population in Cyprus increased by almost 8 per cent. These demographic shifts resulted in a relatively much higher supply pressure on the Cyprian than on the Greek youth labour market.

Looking at its youth employment rate in 2017, Poland appeared to be a European leader with a 9 pp increase since 2007. A closer look reveals that the increase was mostly due to demographic shifts. During the decade under study, the number of employed young Poles decreased by 11 per cent, but during the same period the number of Polish young people declined by nearly 24 per cent. In other words, the demographic changes attenuated the impact of negative trends in the labour market and, as a result, gave an impression of improvements. In the same period, Iceland experienced an increase in employed young people of nearly $5 \mathrm{pp}$, but in the same period the population of young Icelanders increased by 11 per cent and the number of jobs held by young people in the country rose even more - by nearly 18 per cent.

It is worth considering which countries have dealt best with the effects of the recession on the youth labour market situation. Table 4.2 presents the changes in both the number of employed young people and the size of the total population of young people in the period between 2007 and 2017.

Macedonia and Turkey were the countries that seem to have dealt best with the effects of the recession. In both countries, the number of employed young people increased notwithstanding a decrease in the same period in the total population of young people. However, it must be noted that at the beginning of the period (2007) the youth employment-to-population ratio was very low in relative terms in both countries -46 per cent in Turkey and less than 32 per cent in Macedonia.

The eight countries of group 2 (see Table 4.2) not only experienced an increase in the number of young people but also increased the number of jobs occupied by young workers; and the latter rise was relatively stronger. 
Table 4.2 Relative changes in the number of young people and the number of employed young people

\begin{tabular}{|c|c|c|c|c|c|c|}
\hline \multicolumn{7}{|c|}{ Total population of young people (aged 20-29) } \\
\hline \multirow[t]{2}{*}{$\begin{array}{l}\text { Countries where } \\
\text { the number of } \\
\text { employed young } \\
\text { people increased } \\
\text { between } 2007 \mathrm{Q} 1 \\
\text { and } 2017 \mathrm{Q} 1\end{array}$} & \multicolumn{2}{|c|}{ Decreased } & \multicolumn{2}{|c|}{$\begin{array}{l}\text { Increased relatively } \\
\text { LESS than the number } \\
\text { of employed young } \\
\text { people }\end{array}$} & \multicolumn{2}{|c|}{$\begin{array}{l}\text { Increased relatively } \\
\text { MORE than } \\
\text { the number of } \\
\text { employed young } \\
\text { people }\end{array}$} \\
\hline & \multicolumn{2}{|c|}{$\begin{array}{l}\text { (1) } \\
\text { Macedonia, } \\
\text { Turkey }\end{array}$} & \multicolumn{2}{|c|}{$\begin{array}{l}\text { Germany, Luxembourg, } \\
\text { Malta, Austria, Sweden, } \\
\text { United Kingdom, } \\
\text { Iceland, Switzerland }\end{array}$} & & $\begin{array}{l}\text { way, Denmark, } \\
\text { herlands }\end{array}$ \\
\hline \multicolumn{7}{|c|}{ Total population of young people (aged 20-29) } \\
\hline \multirow{2}{*}{$\begin{array}{l}\text { Countries } \\
\text { where the } \\
\text { number of } \\
\text { employed } \\
\text { young people } \\
\text { decreased } \\
\text { between } \\
2007 \text { Q1 and } \\
2017 \text { Q1 }\end{array}$} & Increased & \multicolumn{2}{|c|}{$\begin{array}{l}\text { Decreased } \\
\text { relatively LESS } \\
\text { than the number } \\
\text { of employed } \\
\text { young people }\end{array}$} & \multicolumn{2}{|c|}{$\begin{array}{l}\text { Decreased } \\
\text { relatively } \\
\text { MORE than } \\
\text { the number of } \\
\text { employed young } \\
\text { people }\end{array}$} & $\begin{array}{l}\text { The number of } \\
\text { young people } \\
\text { remained } \\
\text { unchanged } \\
(+/-1 \%)\end{array}$ \\
\hline & $\begin{array}{l}\text { (4) } \\
\text { Belgium, } \\
\text { Cyprus, } \\
\text { Finland }\end{array}$ & $\begin{array}{l}\text { (5) } \\
\text { Spai } \\
\text { Irela } \\
\text { Cro } \\
\text { Port } \\
\text { Slov }\end{array}$ & $\begin{array}{l}\text { n, Bulgaria, } \\
\text { nd, Greece, } \\
\text { tia, Italy, } \\
\text { ugal, } \\
\text { enia }\end{array}$ & $\begin{array}{l}\text { (6) } \\
\text { Poland, } \\
\text { Lithuania, } \\
\text { Czech Repub } \\
\text { Estonia, Latv } \\
\text { Hungary, } \\
\text { Romania, } \\
\text { Slovakia }\end{array}$ & & $\begin{array}{l}(7) \\
\text { France }\end{array}$ \\
\hline
\end{tabular}

Source: Author's own calculation based on Eurostat data (http://ec.europa.eu/eurostat/ statistics).

These countries were a real success story: the level of employment to the population ratio rose despite the increased supply pressure (due to the higher number of young people) and the economic recession, which represented the risks for labour demand.

We can describe the countries of group 6 (see Table 4.2) as countries characterized by 'an apparent improvement'. Counterintuitively, between 2007 and 2017, the situation of young people in these countries improved (see Figure 4.1), despite the fact that the number of jobs taken up by young 
people decreased. The improvement was mostly due to a sharp decrease in the number of young people; for instance, in the first quarter of 2007 the population of young people (20-29) in Poland amounted to slightly more than 6 million, whereas in the first quarter of 2017 it came to 4.6 million. Previous studies have shown that during and after the crisis the labour emigration of Lithuanians and Latvians almost doubled (Gonser, 2011). In 2012 the Baltic States were amongst the EU countries with the largest proportions of emigrating young people to settle in other EU member states (European Commission, 2015). The significant demographic changes in the countries of group 6 were the result of a combined effect of a substantial decrease in fertility rates in the late 1980s and the early 1990s, and emigration, which intensified after joining the European Union.

Emigration of young people might itself represent evidence of difficulties in the labour market that have remained unresolved. The combined consequences of the labour market situation and demographic changes are likely to be experienced in the future. Because the number of jobs taken up by young people has fallen, this may result in difficulties with finding enough employment once the number of young people begins to increase because of growing cohort sizes, immigration and/or return migration.

In the eight countries of group 5, both the number of jobs for youth and the number of young people decreased, but the former decreased relatively more than the latter. Despite the lower number of young people in these countries (in 2017 relative to 2007), their situation in the labour market deteriorated. In other words, the decline in population size only partially mitigated the effects of negative changes in the labour market in the Southern European countries and Ireland.

\section{CONCLUSION}

In this chapter I have analysed demographic changes and their consequences for the labour market situation of young people in Europe between 2007 and 2017. The analysis has shown that both relative (youth as a share of the working-age population) and absolute (youth population size over time) changes in the youth population significantly affect youth employment ratios.

In their paper on the consequences of the Great Recession for youth unemployment, Bell and Blanchflower argued that the conventional wisdom of youth employment policy had turned out to be largely irrelevant during the recession and they suggested that: 'the solution to the youth unemployment problem is simply put - more jobs for young people' (Bell and Blanchflower, 2011: 241). Under conditions of limited 
substitutability between young and old workers, the number of jobs held by the young population represents a major factor in assessing labour market trends. The limited substitutability between younger and older workers means that the changes in the size of cohorts of younger workers do not affect the employment and unemployment rates of older cohorts in the short run. Hence, in the short run a large youth cohort size has an adverse effect on youth employment. Similarly, we may predict that the labour market entry of small cohorts will increase the employment-topopulation ratio and wages of young people. Being a member of a cohort that 'follows' a large cohort may have a positive effect on one's labour market performance.

The youth labour market statistics of many countries are likely to present a misleading picture. If the decrease in the youth unemployment rate or the increase in the employment rate is mostly due to a decline in the size of the youth cohort, then one has to be careful when interpreting the rates. The decline in the number of young people entering the labour market weakens the supply pressure in the short-term perspective and it explains why in many, mostly Eastern European countries, the youth labour market situation measured with (un)employment rates seems to have improved more than in other countries. One must bear in mind that during the ten years analysed here, the population of young people in countries like Latvia, Poland, Slovenia, Lithuania and Slovakia decreased substantially, as did the population of working-age adults. The demographic deficits generated by long-standing low fertility rates and migration to other countries tended to provide temporary benefits to young people in the years immediately after the recession. In the short-term perspective, the pressure on the labour market diminished, and so did the pressure to create new jobs for young people and to undertake necessary reforms. However, in the medium and the long run the decrease in the size of the working-age population will result in a reduction of the human resource base for development and in additional strains on welfare states.

From the policy point of view, the findings concerning employment rates are very suggestive; however, they ignore some vital aspects. The danger of using traditional measurements of youth unemployment is that the apparent improvement of the youth labour market situation will distract governments from efforts to promote youth employment when this is exactly the time for action. If policymakers do not urgently address the situation, not only today's generation but also future generations will suffer the consequences. Additionally, the demographic changes that in the short run result in an improved labour market situation for young people may in the long run lead to many negative consequences. The demographic changes are likely to have negative implications for the following: 
1. Long-term fiscal sustainability as population ageing results in increasing expenditure on healthcare and pensions as a share of GDP;

2. Labour supply: the shortage of workers is likely to generate wage pressures;

3. Productivity: the decline in the working-age population means that growth will be increasingly dependent on labour productivity;

4. Welfare state: in the light of the decreasing share of young people in the working-age population $a^{\circ} \mathrm{d}$ employed population, many aspects of welfare state systems will need to be reformed.

According to World Bank projections, Europe is the fastest ageing continent (Bussolo et al., 2015). Due to the declining share of the population of working age (20-64) in most European countries, old-age dependency ratios are rising. The growth of the dependency ratio has a direct impact on income per capita: it influences the need for increasing labour productivity and implies that every employed person will have to support a larger number of people and consequently will need a higher income to escape from poverty. It is possible, to some extent, to alleviate the negative symptoms of the age-based dependency ratio (i.e., the number of people every working-age person must support) by increasing labour force participation. Thus, as the number of people of working age falls, the number of working individuals may remain unchanged (or even rise). In some countries it is possible to offset labour shortages by mobilizing groups like mothers with young children, low-educated or disabled individuals, and older people, who usually are under-represented on the labour market. However, this means that activation costs are likely to increase, while the effectiveness of activation policy for these groups remains questionable.

\section{REFERENCES}

Apsīte E, Krišjāne Z and Bērziņš M (2012) Emigration from Latvia under economic crisis conditions. In: 2nd international conference on social science and humanity, Singapore, IPEDR, pp. 134-8.

Bell DN and Blanchflower DG (2011) Young people and the Great Recession. Oxford Review of Economic Policy 27(2): 241-67. DOI: 10.1093/oxrep/grr011.

Bloom DE and Canning D (2004) Global demographic change: Dimensions and economic significance. NBER Working Paper no. 10817. Cambridge, MA: National Bureau of Economic Research. DOI: 10.3386/w10817.

Bloom DE, Freeman RB and Korenman S (1987) The labour-market consequences of generational crowding. European Journal of Population 3: 131-76.

Bloom DE and McKenna MJ (2015) Population, labour force and unemployment: Implications for the creation of (decent) jobs, 1990-2030. Background paper. New York: UNDP Human Development Report Office. 
Breen R (2005) Explaining cross-national variation in youth unemployment: Market and institutional factors. European Sociological Review 21(2): 125-34. DOI: $10.1093 /$ esr/jci008.

Brunello G (2009) The effects of cohort size on European earnings. Journal of Population Economics 23(1): 273-90. DOI: 10.1007/s00148-009-0250-y.

Brunello G and Lauer C (2004) Are wages in southern Europe more flexible? The effects of cohort size on European earnings. IZA Discussion Paper no. 1299. Bonn: Institute for the Study of Labor.

Bussolo M, Koettl J and Sinnott E (2015) Golden aging: Prospects for healthy, active, and prosperous aging in Europe and Central Asia. Washington, DC: World Bank. DOI: 10.1596/978-1-4648-0353-6.

Connelly R (1986) A framework for analyzing the impact of cohort size on education and labor earning. The Journal of Human Resources 21(4): 543-62. DOI: $10.2307 / 145766$.

Dixon S (2003) Implications of population ageing for the labour market. Labour Market Trends 111(2): 67-76.

Dolado JJ, Felgueroso F and Jimeno JF (2000) Youth labour markets in Spain: Education, training, and crowding-out. European Economic Review 44(4/6): 943-56. DOI: 10.1016/S0014-2921(99)00050-1.

European Commission (2015) Commission Staff Working Document: Situation of young people in the EU. Brussels: $\operatorname{SWD}(2015) 169$ final.

European Commission (2016) EU Youth Report 2015. Luxembourg: Publications Office of the European Union.

European Commission (2017) Commission Staff Working Document: Country report Denmark 2017. Brussels: SWD(2017) 70 final.

Freeman RB and Wise D (1982) The Youth Labor Market: Its Nature, Causes, and Consequences. Chicago, IL: University of Chicago Press. http://www.nber.org/ books/free82-1 (accessed 1 October 2018).

Gangl M (2002) Changing labour markets and early career outcomes: Labour market entry in Europe over the past decade. Work, Employment \& Society 16(1): 67-90. DOI: 10.1177/09500170222119254.

Gómez-Salvador R and Leiner-Killinger N (2008) An analysis of youth unemployment in the euro area. ECB Occasional Paper no. 89. Frankfurt am Main: European Central Bank. DOI: 10.2139/ssrn.1084915.

Gonser M (2011) More of the same, but faster? The financial crisis and the representation of employee interests in the Baltic States. Transfer: European Review of Labour and Research 17(3): 409-14. DOI: 10.1177/1024258911413526.

Hannan DF, Smyth E and McCoy S (1999) A comparative analysis of transitions from education to work in Europe (CATEWE): A conceptual framework. ESRI Working Paper no. 118. Dublin: Economic and Social Research Institute.

Heylen F, Goubert L and Omey E (1996) Unemployment in Europe: A problem of relative or aggregate labour demand shocks? International Labour Review 135(1): 17-36.

ILO (2015) Global employment trends for youth 2015. Scaling up investments in decent jobs for youth. Geneva: International Labour Office. DOI: 92-2-113360-5.

Knabe A and Rätzel S (2011) Scarring or scaring? The psychological impact of past unemployment and future unemployment risk. Economica 78(310): 283-93. DOI: $10.1111 / \mathrm{j} .1468-0335.2009 .00816 . x$.

Korenman S and Neumark D (2000) Cohort crowding and youth labor markets: 
A cross-national analysis. In: Blanchflower D and Freeman R (eds) Youth Employment and Joblessness in Advanced Countries. Chicago, IL: University of Chicago Press, pp. 57-106. DOI: 10.3386/w6031.

Lewis $\mathbf{P}$ and Heyes J (2017) The changing face of youth employment in Europe. Economic and Industrial Democracy. Epub ahead of print 24 August 2017. DOI: 10.1177/0143831X17720017.

Nahum R and Dahlberg S (2003) Cohort effects on earnings profiles: Evidence from Sweden. Working Paper no. 11. Uppsala: Department of Economics, Uppsala University.

Nilsen ØA and Reiso KH (2011) Scarring effects of unemployment. IZA Discussion Paper no. 6198. Bonn: Institute for the Study of Labor.

O'Higgins N (1997) The challenge of youth unemployment. International Social Security Review 50(4): 63-93. DOI: 10.1111/j.1468-246X.1997.tb01084.x.

O'Higgins N (2012) This time it's different? Youth labour markets during 'The Great Recession'. Comparative Economic Studies 54(2): 395-412. DOI: 10.1057/ ces.2012.15.

OECD (2016a) Society at a Glance 2016: OECD Social Indicators. Paris: OECD. DOI: http://dx.doi.org/10.1787/9789264261488-en.

OECD (2016b) Society at a Glance 2016: OECD Social Indicators. A Spotlight on Youth. Paris: OECD. DOI: 10.1787/soc_glance-2014-en.

Rakauskiene OG and Ranceva O (2014) Youth unemployment and emigration trends. Intellectual Economics 8(1):165-77. DOI: 10.13165/IE-14-8-1-12.

Roth D and Moffat J (2014) Cohort size and youth unemployment in Europe: A regional analysis. Joint Discussion Paper in Economics no. 40. https://www.econ stor.eu/bitstream/10419/105077/1/791119157.pdf (accessed 19 March 2018).

Scarpetta S, Sonnet A and Manfredi T (2010) Rising youth unemployment during the crisis. OECD Social, Employment, and Migration Working Paper no. 106. Paris: OECD. DOI: 10.1787/5kmh79zb2mmv-en.

Solow R (1985) Insiders and outsiders in wage determination. Scandinavian Journal of Economics 87(2): 411-28.

Statistics Estonia (2015) Emigration from Estonia decreased last year. News release no. 57. https://www.stat.ee/news-release-2015-057 (accessed 19 March 2018).

Sunter D (2001) Demography and the labour market. Perspectives on Labour and Income 2(2): 28-39.

Veidemann B (2010) Migration potential of working-age population in Estonia in 2010. Policy Analysis no. 8. Tallinn: Ministry of Social Affairs of Estonia.

Wachter ML and Kim C (1982) Time series changes in youth joblessness, the youth labor market problem: Its nature, causes, and consequences. In: Freeman RB and Wise DA (eds) The Youth Labor Market Problem: Its Nature, Causes, and Consequences. Chicago, IL: University of Chicago Press, pp.1-16. DOI: $10.3386 / \mathrm{w} 0384$. 